\title{
Ultrasound-assisted extraction of bioactive compounds from lemon balm and peppermint leaves
}

\author{
Jana Šic Žlabur, Sandra Voća*, Nadica Dobričević, Stjepan Pliestić, Ante Galić, Ana Boričević, \\ and Nataša Borić
}

Department of Agricultural Technology, Storage and Transport, University of Zagreb, Svetošimunska cesta 25, 10000 Zagreb, Croatia

Received June 18, 2015; accepted November16, 2015

\begin{abstract}
A b s t r a c t. The aim of this study was to investigate the influence of conventional and ultrasound-assisted extraction (frequency, time, temperature) on the content of bioactive compounds as well as on the antioxidant activity of aqueous extracts from fresh lemon balm and peppermint leaves. Total phenols, flavonoids, non-flavonoids, total chlorophylls, total carotenoids, and radical scavenging capacity were determined. Moreover, the relationship between bioactive compounds and antioxidant capacity was studied by linear regression. A significant increase in all studied bioactive compounds during ultrasonic extraction for 5 to $20 \mathrm{~min}$ was found. With the classical extraction method, the highest amounts of total phenols, flavonoids, and antioxidant activity were determined, and the maximum amounts of total chlorophylls and carotenoids were determined during 20 min ultrasonic extraction. The correlation analysis revealed a strong, positive relationship between antioxidant activity and total phenolic compounds.

$\mathrm{K}$ e y w o r d s: total phenol content, chlorophylls, antioxidant activity, conventional extraction, high intensity ultrasound
\end{abstract}

\section{INTRODUCTION}

Phenolic compounds exhibit a high degree of degradation in terms of technological processes and show distinct thermolability, sensitivity to light, the impact of pathogens, mechanical damage to plant tissue cells (Ross et al., 2009). Lately modern, non-invasive extraction techniques of plant metabolites with the main objective of increased extracted compound yield and a shortened period of extraction have been increasingly popularized. One of the mentioned techniques is high-intensity ultrasound, which shows a wide range of application in the technological processes eg inactivation of microorganisms, crystallization, filtration, drying, extraction, homogenization, stimulation of oxida-

*Corresponding author e-mail: svoca@agr.hr tion, emulsifying (Barba et al., 2015a; Deng et al., 2015; Herceg et al., 2009; Koubaa et al., 2015). High intensity ultrasound treatment does not show any degradation rates on the content of bioactive compounds in the treated food products (Koubaa et al., 2015; Šic Žabur et al., 2015; Zinoviadou et al., 2015). In addition, high intensity ultrasound is applicable for extraction of compounds with various chemical structures and is characterized by non-invasive temperatures (Cvjetko Bubalo et al., 2013; Koubaa et al., 2015; Šic Žlabur et al., 2015). The ultrasound technique is extremely simple in application, and usually two types of equipment are used, including:

- a system with a directly immersed ultrasonic probe (transducer)

- an ultrasonic bath.

Phenolic acids, flavonoids, and tannins are the most commonly found polyphenolic compounds in plant extracts (Naik et al., 2006). Phenolic compounds from plant material have recently gained great popularity because of their significant positive effects on human health (Auclair et al., 2008; Barba et al., 2014). Phenolic compounds along with plant pigments (carotenoids, chlorophylls) have proven significant antioxidant activity, which is directly corelated with removal of free radicals and superoxide (Hsu et al., 2013; Sinkovič et al., 2015). Therefore, it is important to emphasize the need to increase the consumption of foodstuffs rich in phenolic compounds aimed at preventive action on human health from cancer disease prevention to occurrence and prevention of cardiovascular diseases (Barba et al., 2014). 
Peppermint (Mentha piperita L.) and lemon balm (Melissa officinalis L.) are mainly used as a spice in many food products (De Vincenzi et al., 1991) and traditionally used for medical purposes (Foster and Tyler, 1993). Peppermint and lemon balm are plant species characterized by a high content of phenolic compounds, mainly flavonoids (Guédon and Pasquier, 1994) but they are also rich in chlorophylls. A number of positive effects of peppermint on human health are known, such as antibacterial (Hajlaoui et al., 2008), antifungal (Bouchra et al., 2003), and insecticidal activity (Saljoqi et al., 2006). Lemon balm is one of the most popular medicinal plants with proven sedative, antispasmodic, antibacterial, antiviral, anti-inflammatory, and antioxidative effect (Yamasaki et al., 1998).

\section{MATERIALS AND METHODS}

Peppermint and lemon balm were cultivated on the experimental field of the Department of Vegetable Crops, Faculty of Agriculture University of Zagreb. The experiments were performed in triplicate. During plant cultivation, no fertilization treatment was applied. Also, the availability of water to plants was exclusively dependent on climatic conditions; irrigation was not applied on the experimental field. Peppermint and lemon balm plants were harvested with the whole stem in mid-June 2014. Before analysis, only green, healthy leaves with no visible signs of damage were torn off from the plant stems, while the stem and leaf petiole were removed. The leaves were washed under cold running water and dried. All chemical analyses were made on leaves and leaf water extracts in triplicate.

The water extracts of plant leaves for each plant material, peppermint and lemon balm, were prepared with a unique procedure: $2 \mathrm{~g}( \pm 0.01)$ of plant leaves were cut into smaller pieces and weighed in an Erlenmeyer flask with a volume of $100 \mathrm{ml}$, onto which $50 \mathrm{ml}$ of distilled water at room temperature $\left(22^{\circ} \mathrm{C}\right)$ were added. Prepared leaf solutions were allowed to stand for $24 \mathrm{~h}$ at room temperature with intermitted shaking. After $24 \mathrm{~h}$, the solutions were filtered through Whatman filter paper and used for the designed chemical analysis.

An ultrasonic bath (Bandelin, RK 103 H, Germany) with frequency $35 \mathrm{kHz}$ and nominal power $140 \mathrm{~W}$ was used for ultrasound extraction. Peppermint and lemon balm water solutions were prepared with a unique procedure: $2 \mathrm{~g}( \pm 0.01)$ of fresh plant leaves were weighed in an Erlenmeyer flask with a volume of $100 \mathrm{ml}$, onto which $50 \mathrm{ml}$ of distilled water at room temperature $\left(22^{\circ} \mathrm{C}\right)$ were added. During the ultrasonic treatment, the time of extraction was $5,10,15,20,25$, and $30 \mathrm{~min}$. After each ultrasonic extraction, solutions were filtered through Whatman filter paper and were used for the designed chemical analysis. During the sonication of the samples, temperature change was measured after $5,10,15,20,25$, and 30 min with an infrared thermometer (Batronix, IC UT-300B, Germany) (Table 1).

The total phenol contents in peppermint and lemon balm leaves (raw material) were determined with the Ough and Amerine (1998) method. In turn, the total phenolic content of peppermint and lemon balm extracts (aqueous solutions) were obtained according to Shukla et al. (2012) with some modification during the analysis. Measurement was carried out as follows: $1 \mathrm{ml}$ of the prepared aqueous extract and $1 \mathrm{ml}$ of the Folin-Ciocalteu reagent diluted with distilled water $(1: 2)$ were added in the volumetric flask with a volu$\mathrm{me}$ of $50 \mathrm{ml}$ and allowed to stand for $3 \mathrm{~min}$. Additionally, $3 \mathrm{ml}$ of a saturated sodium carbonate solution was added, the flask was filled to the mark with distilled water and allowed to stand for $3 \mathrm{~h}$ at room temperature with intermittent shaking. The absorbance of the blue colour that developed was measured spectrophotometrically (Shimadzu UV 1650 PC) at $750 \mathrm{~nm}$ with distilled water as a blank. The flavonoid content of the peppermint and lemon balm extracts were determined with the Abou-Arab and Abou-Salem (2010) method with some modification during the analysis: $1 \mathrm{ml}$ of

T a b l e 1. Experimental conditions

\begin{tabular}{|c|c|c|c|c|c|}
\hline $\begin{array}{l}\text { Extraction } \\
\text { technique }\end{array}$ & Solvent & $\begin{array}{l}\text { Solvent volume } \\
(\mathrm{ml})\end{array}$ & Time & $\begin{array}{c}\text { Temperature } \\
\left({ }^{\circ} \mathrm{C}\right)\end{array}$ & $\begin{array}{c}\text { Ultrasonic } \\
\text { bath }\end{array}$ \\
\hline Conventional & Distilled water & 50 & $24 \mathrm{~h}$ & 22.1 & - \\
\hline \multirow{6}{*}{ UAE } & \multirow{6}{*}{ Distilled water } & \multirow{6}{*}{50} & $5 \mathrm{~min}$ & 28.2 & \multirow{6}{*}{$35 \mathrm{kHz} / 140 \mathrm{~W}$} \\
\hline & & & $10 \mathrm{~min}$ & 40.3 & \\
\hline & & & $15 \mathrm{~min}$ & 46.0 & \\
\hline & & & $20 \mathrm{~min}$ & 54.2 & \\
\hline & & & $25 \mathrm{~min}$ & 54.7 & \\
\hline & & & $30 \mathrm{~min}$ & 56.4 & \\
\hline
\end{tabular}

UAE - ultrasound assisted extraction. 
the prepared aqueous extracts, $1 \mathrm{ml}$ of $20 \%(\mathrm{v} / \mathrm{v}) \mathrm{HCl}$, and $0.5 \mathrm{ml}$ formaldehyde were added in the volumetric flask with a volume of $25 \mathrm{ml}$. The prepared samples were purged with nitrogen $\left(\mathrm{N}_{2}\right)$ and allowed to stand for $24 \mathrm{~h}$ at room temperature. After $24 \mathrm{~h}$, the same Folin-Cioacalteu reaction as for total phenols was performed. The absorbance of the blue colour that developed was measured spectrophotometrically (Shimadzu UV $1650 \mathrm{PC}$ ) at $750 \mathrm{~nm}$ with distilled water as a blank. The non-flavonoid content was expressed mathematically as the difference between total phenols and flavonoids. Gallic acid was used as an external standard and the concentration of total phenols, flavonoids, and non-flavonoids was expressed as $\mathrm{mg} \mathrm{g}^{-1}$ of the aqueous extract.

The content of total chlorophylls (chlorophyll a and chlorophyll b) and total carotenoids were determined by Holm (1954) and Wettstein (1957). The sample was weighed into a test tube and $10 \mathrm{ml}$ of acetone was added.The solution prepared in this way was homogenized with a laboratory homogenizer (IKA, UltraTurax T-18, Germany). The solution was filtered and transferred into a volumetric flask with a known volume. The absorbance was measured spectrophotometrically (Shimadzu UV 1650 PC) at 662, 644, and $440 \mathrm{~nm}$ with acetone as a blank probe. The absorbance values were recalculated according to the Holm-Wettstein equations in the pigment concentration $\left(\mathrm{mg} \mathrm{l}^{-1}\right)$, and the final result of the pigment content was expressed in $\mathrm{mg} \mathrm{g}^{-1}$ :

$$
\begin{aligned}
& \text { chlorophyll } \mathrm{a}=9.784 \mathrm{~A}_{662}-0.990 \mathrm{~A}_{644}, \\
& \text { chlorophyll } \mathrm{b}=21.426 \mathrm{~A}_{644^{-}}-4.65 \mathrm{~A}_{662}, \\
& \text { chlorophyll } \mathrm{a}+\mathrm{b}=5.134 \mathrm{~A}_{662}+20.436 \mathrm{~A}_{644}, \\
& \text { carotenoids }=4.695 \mathrm{~A}_{440}-0.268 \text { (chlorophyll } \mathrm{a}+\mathrm{b} \text { ). }
\end{aligned}
$$

The antioxidant activity of leaves and aqueous extracts of peppermint and lemon balm leaves was determined with the ABTS method. Trolox (6-hydroxy-2,5,7,8-tetramethylchroman-2-carboxylic acid; SigmaAldrich) was used as an antioxidant standard. Trolox $(2.5 \mathrm{mM})$ was prepared in ethanol $(80 \%)$ for use as a stock standard. ABTS, 2,2'-azinobis(3-ethylbenzothiazoline-6-sulfonic acid), and potassium persulfate were obtained from Sigma-Aldrich. The experiments were performed according to Miller et al. (1993). ABTS (7 mM) and potassium persulfate $(140 \mathrm{mM})$ were dissolved in distilled water. These two solutions were mixed ( $88 \mu 1$ of prepared potassium persulfate $(140 \mathrm{mM})$ and $5 \mathrm{ml}$ of prepared ABTS solution) and the mixture was allowed to stand in the dark at room temperature for $16 \mathrm{~h}$ before use in order to produce ABTS radicals (ABTS•+). On the day of the analysis, $1 \%$ ABTS $\bullet+$ solution $(1 \mathrm{ml}$ ABTS $\bullet+$ in a volumetric flask of $100 \mathrm{ml}$ filled with $96 \%$ ethanol to the mark) was prepared. For the study, the absorbance of the ABTS radical solution was measured at $734 \mathrm{~nm}$ and set to absorbance of $0.70 \pm 0.02 .160 \mu \mathrm{l}$ of the extracts obtained were directly injected in the cuvette, mixed with
$2 \mathrm{ml} \mathrm{1 \%}$ ABTS $\bullet$, and absorbance was measured at $734 \mathrm{~nm}$. The final results of the antioxidant activity was calculated based on the calibration curve and expressed as mmol TE $\mathrm{l}^{-1}$.

Statistical analysis was performed using the $\mathrm{SAS}^{\circledR}$ version 9.3. Data were subjected to the one-way analysis of variance (ANOVA) according to the treatment structure. Mean values were compared by the t-test (LSD), and they were considered significantly different at $\mathrm{p} \leq 0.05$. Regression and correlation analysis were performed in order to investigate the nature and intensity of the relationships between bioactive compounds and antioxidant activity in vitro. Correlation coefficients with $\mathrm{p}$ values $\leq 0.05$ were considered significant.

\section{RESULTS AND DISCUSSION}

A high statistically significant difference $(\mathrm{p} \leq 0.0001)$ was observed for all the analysed chemical compounds depending on the extraction technique (Table 2). The amount of total phenolic compounds in fresh lemon balm leaves was $1977.45 \mathrm{mg} \mathrm{l}^{-1}$. Many literature data indicate a high content of phenolic compounds in lemon balm leaves (Dastmalchi et al., 2008; Komes et al., 2011; Najafian and Rowshan, 2013). The aqueous samples of lemon balm leaves extracted with the classical method for $24 \mathrm{~h}$ at room temperature show a high content of phenolic compounds with the determined total phenol content of $1331.54 \mathrm{mg} \mathrm{l}^{-1}$. The aqueous samples of lemon balm leaves extracted by high intensity ultrasound in an ultrasonic bath show a significant increase in phenolic compounds depending on the extraction time. The content of all the phenolic compounds studied show an increasing trend in the time of ultrasonic extraction from 5 to $25 \mathrm{~min}$. During the period mentioned, the total phenol content increased by about 6.5 times. The highest value of the total phenolic content in the samples treated with ultrasound was determined in UES5 during 25 min of extraction (Table 2), while sample UES6 (extraction time $30 \mathrm{~min}$ ) had even a lower content of phenolic compounds than sample UES4. The increasing trend of the total phenol content during the ultrasonic treatment for $30 \mathrm{~min}$ is expected, since the extraction time plays a key role in the separation of chemical compounds (Koubaa et al., 2015; Šic Žlabur et al., 2015). The results of total phenols extracted with the classical method show higher yields compared to the phenol results obtained in samples treated with ultrasound. In aqueous samples of lemon balm leaves extracted classically, only 1.5 -fold higher total phenol content was determined compared to sample UES5. During the classical extraction, even $24 \mathrm{~h}$ was required to extract the high content of phenolic compounds. High-intensity ultrasound shows significantly better results compared to conventional extraction because already during $25 \mathrm{~min}$ of application thereof a very high content of phenolic compounds (891.76 $\mathrm{mg} \mathrm{l}^{-1}$ of extract) was achieved. The results obtained are in agreement with other literature data 
T a b l e 2. Total phenol, non-flavonoid, flavonoid content and antioxidant capacity of leaves and aqueous samples of lemon balm leaves extracted with utrasound and classical methods

\begin{tabular}{|c|c|c|c|c|}
\hline \multirow{2}{*}{ Extraction technique } & Total phenols & Non-flavonoids & Flavonoids & Antioxidant capacity \\
\hline & \multicolumn{3}{|c|}{ (mg $\mathrm{l}^{-1}$ extract) } & $\left(\mathrm{mmol} \mathrm{TE}^{-1}\right)$ \\
\hline Leaves & $1977.45 \pm 4.53 \mathrm{a}$ & $1739.46 \pm 1.335 \mathrm{a}$ & $237.99 \pm 0.45 \mathrm{~d}$ & $2.42 \pm 12.77 \mathrm{a}$ \\
\hline Classical extraction & $1331.54 \pm 0.575 \mathrm{~b}$ & $750.90 \pm 1.82 \mathrm{~b}$ & $580.64 \pm 1.25 \mathrm{a}$ & $2.29 \pm 16.5 \mathrm{~b}$ \\
\hline UES1 & $138.11 \pm 0.765 \mathrm{~h}$ & $80.31 \pm 1.45 \mathrm{~h}$ & $57.79 \pm 1.36 \mathrm{~h}$ & $1.91 \pm 5.8 \mathrm{e}$ \\
\hline UES2 & $225.92 \pm 0.45 \mathrm{~g}$ & $144.82 \pm 0.45 \mathrm{~g}$ & $81.10 \pm 0.02 \mathrm{~g}$ & $1.99 \pm 3.0 \mathrm{ed}$ \\
\hline UES3 & $310.86 \pm 0.07 \mathrm{f}$ & $210.40 \pm 0.065 \mathrm{f}$ & $100.46 \pm 0.45 \mathrm{f}$ & $2.09 \pm 15.3 \mathrm{~cd}$ \\
\hline UES4 & $720.93 \pm 1.92 \mathrm{~d}$ & $500.16 \pm 1.92 \mathrm{~d}$ & $213.02 \pm 0.6 \mathrm{e}$ & $2.10 \pm 16.86 \mathrm{~cd}$ \\
\hline UES5 & $891.76 \pm 0.825 \mathrm{c}$ & $507.92 \pm 0.065 \mathrm{c}$ & $391.61 \pm 1.255 \mathrm{~b}$ & $2.17 \pm 4.15 \mathrm{c}$ \\
\hline UES6 & $637.97 \pm 0.45 \mathrm{e}$ & $290.36 \pm 0.125 \mathrm{e}$ & $347.61 \pm 0.355 \mathrm{c}$ & $2.05 \pm 3.2 \mathrm{~d}$ \\
\hline
\end{tabular}

UES1, UES2, UES3, UES4, UES5, UES6 - ultrasound extracted samples: 5, 10, 15, 20, 25, and 30 min, respectively. Different letters indicate significant differences between means at $\mathrm{p}<0.0001$.

(İnce et al., 2013). The antioxidant activity is in correlation with the total phenolic content, vitamins, and generally bioactive compounds (Barba et al., 2010, 2013; CarbonellCapella et al., 2014; Criado et al., 2014). According to the results obtained in this study, a strong relationship between antioxidant activity and the content of total phenolic compounds, flavonoids, and non-flavonoids in the aqueous samples of fresh lemon balm leaves extracted with the classical and ultrasonic methods was determined (Table 3). The highest antioxidant activity was determined in a sample

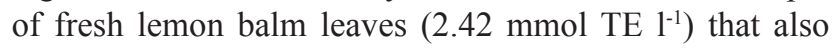
contains the highest amount of all the studied phenolic compounds. The antioxidant activity was the lowest in the aqueous extract of lemon balm leaves treated with ultrasound for $5 \mathrm{~min}$ (UES1), in which the total phenol content was the lowest. The increasing trend of antioxidant activity was determined for samples UES2, UES3, UES4, and UES5, while, as expected, sample UES6 showed the lowest antioxidant activity. The aqueous samples of lemon balm leaves extracted classically showed high antioxidant activity. Generally, lemon balm is exceptionally rich in phenolic compounds. The results of this research indicate a high content of phenolic compounds in all the studied aqueous extracts of lemon balm leaves as well as strong antioxidant activity and are in line with other literature data (Caniova and Brandsteterova, 2001; İnce et al., 2013; Karasová and Lehotay, 2006).

The linear regression between the antioxidant activity and the total phenol content of lemon balm aqueous extracts is presented in Fig. 1a. The total phenol content of the lemon balm aqueous extracts was found to correlate significantly with the antioxidant activity (ABTS). In this research, the relationship between the antioxidant activity
T a b l e 3. Correlation coefficients ( $r$ ) between the selected che-

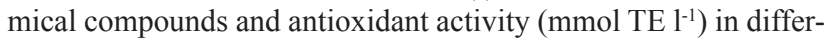
ent aqueous extracts of lemon balm and peppermint leaf samples

\begin{tabular}{|c|c|}
\hline Lemon balm aqueous extracts & Antioxidant activity \\
\hline Total phenols & $0.932 * * *$ \\
\hline Total flavonoids & $0.869 * *$ \\
\hline Non flavonoids & $0.938 * * *$ \\
\hline Total chlorophylls & $0.444 \mathrm{NS}$ \\
\hline Chlorophyll a & $0.380 \mathrm{NS}$ \\
\hline Chlorophyll b & $0.471 \mathrm{NS}$ \\
\hline Total carotenoids & $0.800^{*}$ \\
\hline \multicolumn{2}{|l|}{ Peppermint aqueous extracts } \\
\hline Total phenols & $0.874 * *$ \\
\hline Total flavonoids & $0.961 * * *$ \\
\hline Non flavonoids & $0.836^{* *}$ \\
\hline Total chlorophylls & $0.019 \mathrm{NS}$ \\
\hline Chlorophyll a & $-0.078 \mathrm{NS}$ \\
\hline Chlorophyll b & $0.091 \mathrm{NS}$ \\
\hline Total carotenoids & $0.549 \mathrm{NS}$ \\
\hline
\end{tabular}

$* 0.01<\mathrm{p}<0.05, * * \mathrm{p}<0.001, * * * \mathrm{p}<0.0001, \mathrm{NS}-$ not significant. 


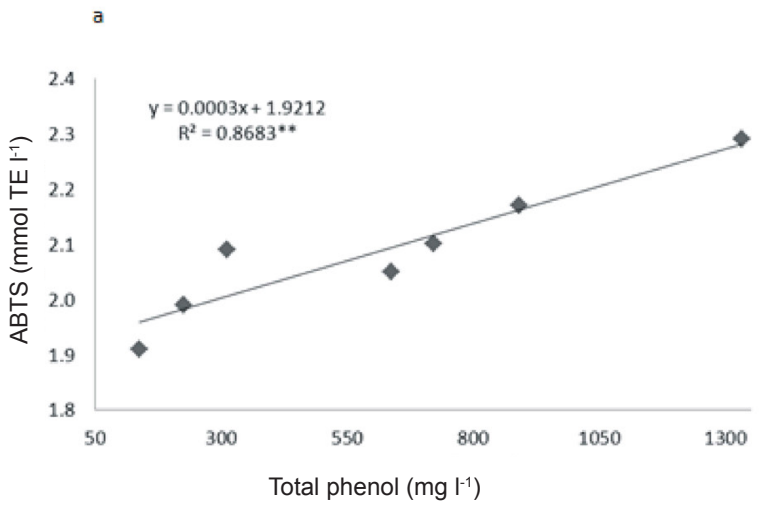

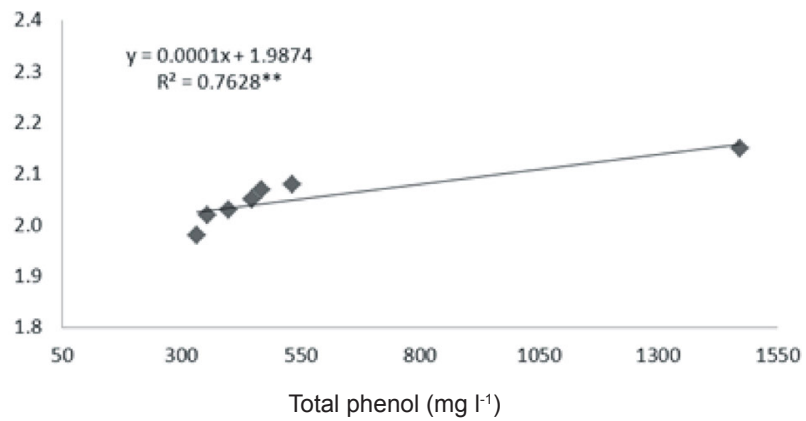

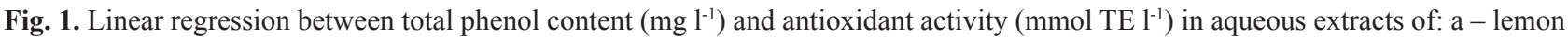
balm and $\mathrm{b}$ - peppermint leaf samples. The significance of the correlation coefficient $(\mathrm{r})$ is marked with asterisks $(* *=$ significance at $\mathrm{p} \leq 0.001)$.

and total phenols was linear with a coefficient of determination $\mathrm{R}^{2}=0.8683$, which assumes a strong relationship between the observed parameters. Table 3 shows the results of the correlation coefficients ( $\mathrm{r}$ ) between the total phenol content $\left(\mathrm{mg} \mathrm{l}^{-1}\right)$ and antioxidant activity (mmol TE $\left.{ }^{-1}\right)$ in the aqueous samples of lemon balm leaves extracted with the classical method and with ultrasound. A high correlation coefficient $(\mathrm{p} \leq 0.0001)$ was observed between the total phenol content $(\mathrm{r}=0.932)$, non-flavonoids $(\mathrm{r}=0.938)$, and antioxidant activity of lemon balm aqueous leaf extracts.

Table 4 presents the results of the total phenolic, flavonoid, and non-flavonoid content and antioxidant activity of fresh peppermint leaves and aqueous leaf samples extracted classically and with ultrasound. A high significant statistical difference $(p \leq 0.0001)$ was observed for all the analysed phenol compounds (total phenols, flavonoids, and non-flavonoids) depending on the extraction technique. In the samples of fresh peppermint leaves, a high content of total phenols (1722.25 $\mathrm{mg} \mathrm{l}^{-1}$ ) was determined, which is a slightly lower value, compared with the total phenol content of fresh lemon balm leaves. The results obtained are consistent with other literature data, which emphasize a significantly high phenol content of peppermint leaves (Lv et al., 2012; Kapp et al., 2013; Riachi and De Maria, 2015). During the $24 \mathrm{~h}$ of classical extraction of fresh peppermint leaves in water, the total phenol content was $1472.49 \mathrm{mg} \mathrm{l}^{-1}$, which is an about $15 \%$ lower value in comparison with the total phenol content identified in fresh leaves. Based on the data above mentioned, it should be emphasized that the applied classical extraction method significantly contributed to the separation of phenolic compounds. During the ultrasonic extraction of the aqueous peppermint samples, an about $60 \%$ increase in the total phenol content in the period from 5 to 25 min was determined. The lower total phenol content was determined during ultrasonic extraction in a maximum applied time of $30 \mathrm{~min}$. An increasing trend of the total flavonoid and non-flavonoid content during ultrasonic extraction for

T a b l e 4. Total phenol, non-flavonoid, and flavonoid content and antioxidant capacity of leaves and aqueous samples of peppermint leaves extracted with the ultrasound and classical methods

\begin{tabular}{lcccc}
\hline & Total phenols & Non-flavonoids & Flavonoids & Antioxidant capacity \\
\cline { 2 - 5 } Extraction technique & & $\left(\mathrm{mg} \mathrm{l}^{-1}\right.$ extract $)$ & $\left(\mathrm{mmol} \mathrm{TE} \mathrm{1}^{-1}\right)$ \\
\hline Leaves & $1722.25 \pm 2.62 \mathrm{a}$ & $1132.96 \pm 0.99 \mathrm{a}$ & $589.29 \pm 3.61 \mathrm{a}$ & $2.30 \pm 0.375 \mathrm{a}$ \\
Classical extraction & $1472.49 \pm 0.765 \mathrm{~b}$ & $1080.76 \pm 1.28 \mathrm{~b}$ & $391.73 \pm 0.515 \mathrm{~b}$ & $2.15 \pm 5.12 \mathrm{~b}$ \\
UES1 & $332.45 \pm 1.595 \mathrm{~h}$ & $200.91 \pm 0.705 \mathrm{~h}$ & $131.54 \pm 2.3 \mathrm{~h}$ & $1.98 \pm 0.62 \mathrm{~d}$ \\
UES2 & $355.57 \pm 0.575 \mathrm{~g}$ & $213.81 \pm 1.345 \mathrm{~g}$ & $141.76 \pm 0.77 \mathrm{~g}$ & $2.02 \pm 18,87 \mathrm{~cd}$ \\
UES3 & $399.31 \pm 0.01 \mathrm{f}$ & $222.81 \pm 1.15 \mathrm{f}$ & $176.50 \pm 1.15 \mathrm{f}$ & $2.03 \pm 8.1 \mathrm{~cd}$ \\
UES4 & $449.45 \pm 0.705 \mathrm{e}$ & $263.29 \pm 0.755 \mathrm{~d}$ & $186.15 \pm 1.47 \mathrm{e}$ & $2.05 \pm 1.645 \mathrm{~cd}$ \\
UES5 & $534.07 \pm 0.125 \mathrm{c}$ & $288.08 \pm 0.01 \mathrm{c}$ & $245.99 \pm 0.125 \mathrm{c}$ & $2.08 \pm 1.56 \mathrm{bc}$ \\
UES6 & $467.55 \pm 0.955 \mathrm{~d}$ & $257.77 \pm 1.15 \mathrm{e}$ & $209.78 \pm 0.195 \mathrm{~d}$ & $2.07 \pm 1.405 \mathrm{bcd}$ \\
\hline
\end{tabular}

Explanations as in Table 2. 
a period from 5 to 25 min was recorded. The antioxidant activity of fresh peppermint leaves was lower than the antioxidant values determined for fresh lemon balm leaves, which was expected, since fresh lemon balm leaves had higher total phenol content. Oh et al. (2013) and Riachi and De Maria (2015) emphasize the very high antioxidant capacity of aqueous peppermint solutions, comparing different methods for testing the antioxidant activity (FRAP, ORAC, ABTS, DPPH).

A strong correlation between total phenolic compounds (flavonoids and non-flavonoids) of peppermint samples (extracted classically and with ultrasound) and antioxidant activity was determined. The linear regression between antioxidant activity measured with the ABTS method and the total phenol content of the peppermint aqueous extracts are presented in Fig. 1b. The total phenol content of peppermint aqueous extracts was found to correlate significantly with the antioxidant capacity (ABTS). The relationship between antioxidant capacity and total phenolic compounds was linear with a coefficient of determination $\mathrm{R}^{2}=0.7628$, which assumes a strong relationship between the observed parameters. A high correlation coefficient $(\mathrm{p} \leq 0.0001)$ was observed between the total flavonoids $(\mathrm{r}=0.961)$, total phenol content $(\mathrm{r}=0.874)$, non-flavonoids $(\mathrm{r}=0.836$ with $\mathrm{p} \leq 0.001)$ and antioxidant activity of peppermint aqueous leaf extracts (Table 3 ).

The total chlorophyll, chlorophyll a, chlorophyll b, and carotenoid content of fresh lemon balm and peppermint leaves and their aqueous samples extracted classically and ultrasonic are shown in Tables 5 and 6. Lemon balm

T a b I e 5. Total chlorophylls, chlorophyll a, chlorophyll b, and total carotenoids in leaves and aqueous samples of lemon balm leaves extracted with the ultrasound and classical methods

\begin{tabular}{|c|c|c|c|c|}
\hline \multirow{2}{*}{ Extraction technique } & Total chlorophylls & Chlorophyll a & Chlorophyll b & Total carotenoids \\
\hline & \multicolumn{4}{|c|}{$\left(\mathrm{mg} \mathrm{g}^{-1}\right)$} \\
\hline Leaves & $177.21 \pm 1.92 \mathrm{a}$ & $115.57 \pm 1.16 \mathrm{a}$ & $61.64 \pm 0.76 \mathrm{a}$ & $56.09 \pm 0.22 \mathrm{a}$ \\
\hline Classical extraction & $2.79 \pm 0.94 \mathrm{~d}$ & $0.83 \pm 0.29 \mathrm{~cd}$ & $1.96 \pm 0.64 \mathrm{de}$ & $3.83 \pm 0.85 \mathrm{~b}$ \\
\hline UES1 & $0.93 \pm 0.01 \mathrm{e}$ & $0.31 \pm 0.01 \mathrm{~d}$ & $0.62 \pm 0.01 \mathrm{f}$ & $0.56 \pm 0.004 \mathrm{~g}$ \\
\hline UES2 & $2.24 \pm 0.04 \mathrm{de}$ & $0.74 \pm 0.015 \mathrm{~cd}$ & $1.49 \pm 0.03 \mathrm{e}$ & $0.79 \pm 0.004 \mathrm{f}$ \\
\hline UES3 & $3.01 \pm 0.11 \mathrm{~d}$ & $0.99 \pm 0.04 \mathrm{~cd}$ & $2.02 \pm 0.07 \mathrm{de}$ & $1.03 \pm 0.02 \mathrm{e}$ \\
\hline UES4 & $6.39 \pm 0.02 \mathrm{~b}$ & $2.16 \pm 0.007 \mathrm{~b}$ & $4.23 \pm 0.013 \mathrm{~b}$ & $3.85 \pm 0.02 \mathrm{~b}$ \\
\hline UES5 & $4.64 \pm 0.09 \mathrm{c}$ & $1.55 \pm 0.04 \mathrm{bc}$ & $3.09 \pm 0.05 \mathrm{c}$ & $3.01 \pm 0.03 \mathrm{c}$ \\
\hline UES6 & $3.24 \pm 0.06 \mathrm{~cd}$ & $1.06 \pm 0.01 \mathrm{~cd}$ & $2.19 \pm 0.045 \mathrm{~d}$ & $2.35 \pm 0.004 \mathrm{~d}$ \\
\hline
\end{tabular}

Explanations as in Table 2.

T a b l e 6. Total chlorophylls, chlorophyll a, chlorophyll b, and total carotenoids of leaves and aqueous samples of peppermint leaves extracted with the ultrasound and classical methods

\begin{tabular}{lcccc}
\hline & Total chlorophylls & Chlorophyll a & Chlorophyll b & Total carotenoids \\
\cline { 2 - 5 } Extraction technique & \multicolumn{2}{c}{$\left(\mathrm{mg} \mathrm{g}^{-1}\right)$} & & $163.43 \pm 1.53 \mathrm{a}$ \\
\hline Leaves & $703.15 \pm 6.67 \mathrm{a}$ & $454.48 \pm 4.04 \mathrm{a}$ & $248.66 \pm 2.63 \mathrm{a}$ & $6.66 \pm 0.21 \mathrm{~b}$ \\
Classical extraction & $4.37 \pm 0.64 \mathrm{f}$ & $1.33 \pm 0.23 \mathrm{~h}$ & $3.04 \pm 0.41 \mathrm{f}$ & $2.72 \pm 0.015 \mathrm{f}$ \\
UES1 & $4.10 \pm 0.001 \mathrm{~g}$ & $1.45 \pm 0.02 \mathrm{~g}$ & $2.58 \pm 0.04 \mathrm{~g}$ & $3.06 \pm 0.017 \mathrm{e}$ \\
UES2 & $5.04 \pm 0.04 \mathrm{e}$ & $1.83 \pm 0.006 \mathrm{e}$ & $3.21 \pm 0.03 \mathrm{e}$ & $3.32 \pm 0.011 \mathrm{~d}$ \\
UES3 & $5.39 \pm 0.001 \mathrm{~d}$ & $1.96 \pm 0.001 \mathrm{~d}$ & $3.43 \pm 0.001 \mathrm{~d}$ & $5.49 \pm 0.04 \mathrm{c}$ \\
UES4 & $9.84 \pm 0.102 \mathrm{~b}$ & $3.55 \pm 0.03 \mathrm{~b}$ & $6.29 \pm 0.07 \mathrm{~b}$ & $3.28 \pm 0.04 \mathrm{~d}$ \\
UES5 & $6.77 \pm 0.123 \mathrm{c}$ & $2.40 \pm 0.04 \mathrm{c}$ & $4.37 \pm 0.08 \mathrm{c}$ & $2.93 \pm 0.04 \mathrm{f}$ \\
UES6 & $4.52 \pm 0.06 \mathrm{f}$ & $1.59 \pm 0.02 \mathrm{f}$ & $1.09 \pm 0.001 \mathrm{~g}$ \\
\hline
\end{tabular}

Explanations as in Table 2. 
and peppermint are characterized by high content of green pigments, chlorophylls, which is confirmed by numerous scientific investigations (Grzeszczuk and Jadczak, 2009; Loranty et al., 2010; Komes et al., 2011). According to the result of this research, fresh lemon balm leaves contained on average 177.21, 115.57, and $61.64 \mathrm{mg} \mathrm{g}^{-1}$ of total chlorophylls, chlorophyll a, and chlorophyll b; while fresh peppermint leaves exhibited significantly higher amounts: $703.15,454.48$, and $248.66 \mathrm{mg} \mathrm{g}^{-1}$ of total chlorophylls, chlorophyll a, and chlorophyll b, respectively. Fresh lemon balm and peppermint leaves also contained significant amounts of total carotenoids: lemon balm $56.09 \mathrm{mg} \mathrm{g}^{-1}$ and peppermint even three times higher ie $163.43 \mathrm{mg} \mathrm{g}^{-1}$. The extraction technique significantly affected the total chlorophyll (chlorophyll a and chlorophyll b) and carotenoid content in lemon balm and peppermint aqueous samples with $p$ value less than 0.0001 . During the ultrasonic extraction of lemon balm leaves for 20 min (UES4), a significant increase in the total chlorophyll content was determined, even $56 \%$ higher compared with the samples extracted classically. Also, the same increasing trend during ultrasonic extraction for $20 \mathrm{~min}$ was determined for the chlorophyll a and chlorophyll b content. The chlorophyll a content was even $62 \%$, and chlorophyll b 54\% higher compared to the samples extracted classically. In the period from 25 (UES5) to 30 min (UES6) of ultrasonic extraction, a significant decrease in the total chlorophyll (chlorophyll a and b) content was determined, but the final value was still higher than the value obtained in the sample extracted classically. Numerous literature data emphasize the extreme effectiveness and significant yields in the application of the ultrasound techniques in the extraction of chlorophylls and its derivatives from various plant materials (Barba et al., 2015b; Grimi et al., 2014; Roselló-Soto et al., 2015a, 2015b). In their research, Kong et al. (2014) emphasize a significant yield increase $(59 \%)$ in total chlorophyll content recovered from a Chlorella vulgaris residue by ultrasound application compared to conventional heat

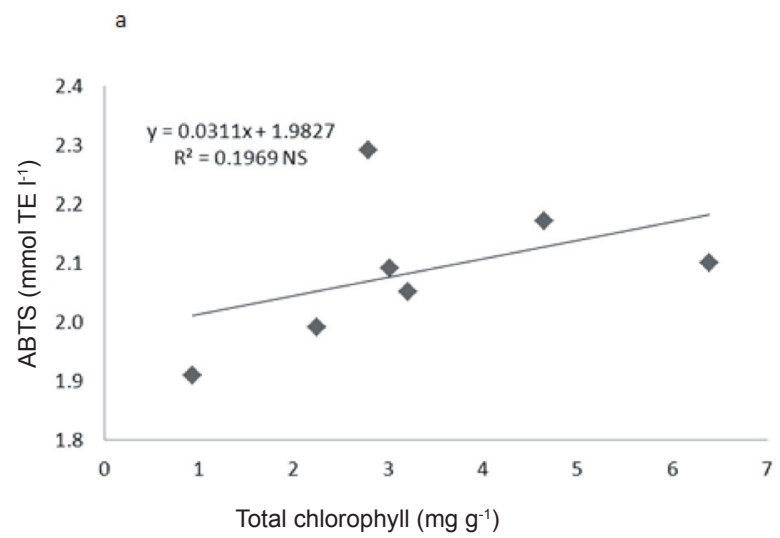

extraction. The total carotenoid content determined in fresh lemon balm leaves was $56.09 \mathrm{mg} \mathrm{g}^{-1}$, which is a significantly lower value than the value determined for the carotenoid content in fresh peppermint leaves $\left(163.43 \mathrm{mg} \mathrm{g}^{-1}\right)$. Also, the carotenoid content significantly changed depending on the applied extraction technique in the samples of lemon balm and peppermint leaves. The highest total carotenoid content was determined for the aqueous samples of lemon balm leaves extracted with ultrasound $\left(3.83 \mathrm{mg} \mathrm{g}^{-1}\right)$, while the highest content $6.66 \mathrm{mg} \mathrm{g}^{-1}$ in the aqueous samples of peppermint leaves was determined by applying the classical extraction. During the ultrasonic extraction of the lemon balm samples in the period from 5 to $20 \mathrm{~min}$, an increase in the total carotenoid content from 0.56 (UES1) to $3.85 \mathrm{mg} \mathrm{g}^{-1}$ (UES4) was determined, which is an increase by approximately $85 \%$. In the period of 25 (UES5) and 30 min (UES6) of ultrasonic extraction, a decrease in the total carotenoid content was determined. At the ultrasonic extraction of the aqueous peppermint leaf samples, an increase in the total carotenoid content in the period from 5 to 20 min was determined, with the highest value of $5.49 \mathrm{mg} \mathrm{g}^{-1}$ (UES4), which is an increase by about $51 \%$. The increasing trend for the total carotenoid content is in line with other literature data, which emphasize the extreme effectiveness of ultrasound in carotenoid extraction from various plant materials such as carrots, algae, tomatoes etc. in comparison with the classical techniques (Kumcuoglu et al., 2014; Roselló-Soto et al., 2015b).

Figures 2 and 3 show linear regression between the total chlorophyll and total carotenoid contents $\left(\mathrm{mg} \mathrm{g}^{-1}\right)$, and antioxidant activity (mmol TE $\mathrm{m}^{-1}$ ) measured in different aqueous extracts of lemon balm and peppermint leaves. Linear regression analysis between the total chlorophyll content and antioxidant activity of aqueous lemon balm and peppermint samples did not show a significant correlation (Fig. 2), which was also determined by analysing the correlation coefficients (Table 3). The results obtained differ from other literature data. Namely, chlorophylls are chemical

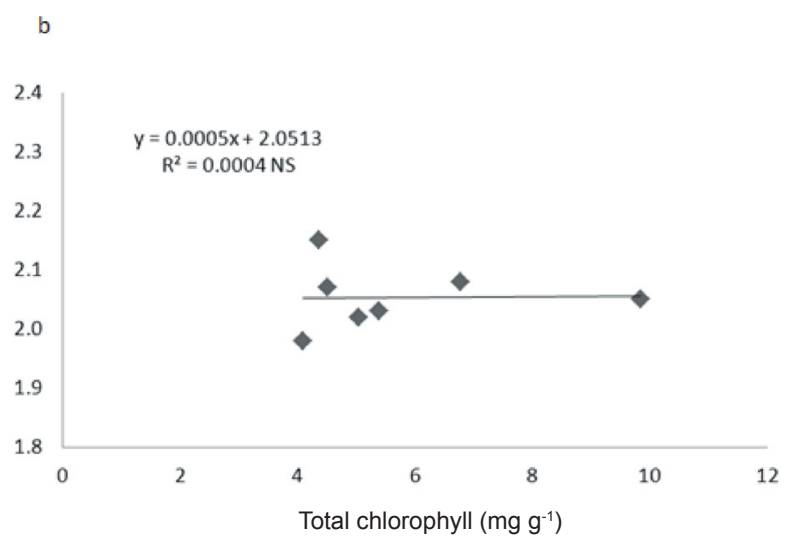

Fig. 2. Linear regression between the total chlorophyll content $\left(\mathrm{mg} \mathrm{g}^{-1}\right)$ and antioxidant activity (mmol TE $\left.{ }^{-1}\right)$ in the aqueous extracts of: $\mathrm{a}-$ lemon balm and b-peppermint leaf samples. Significance of the correlation coefficient (r) is marked with asterisks, ***significance at $\mathrm{p} \leq 0.0001$. 

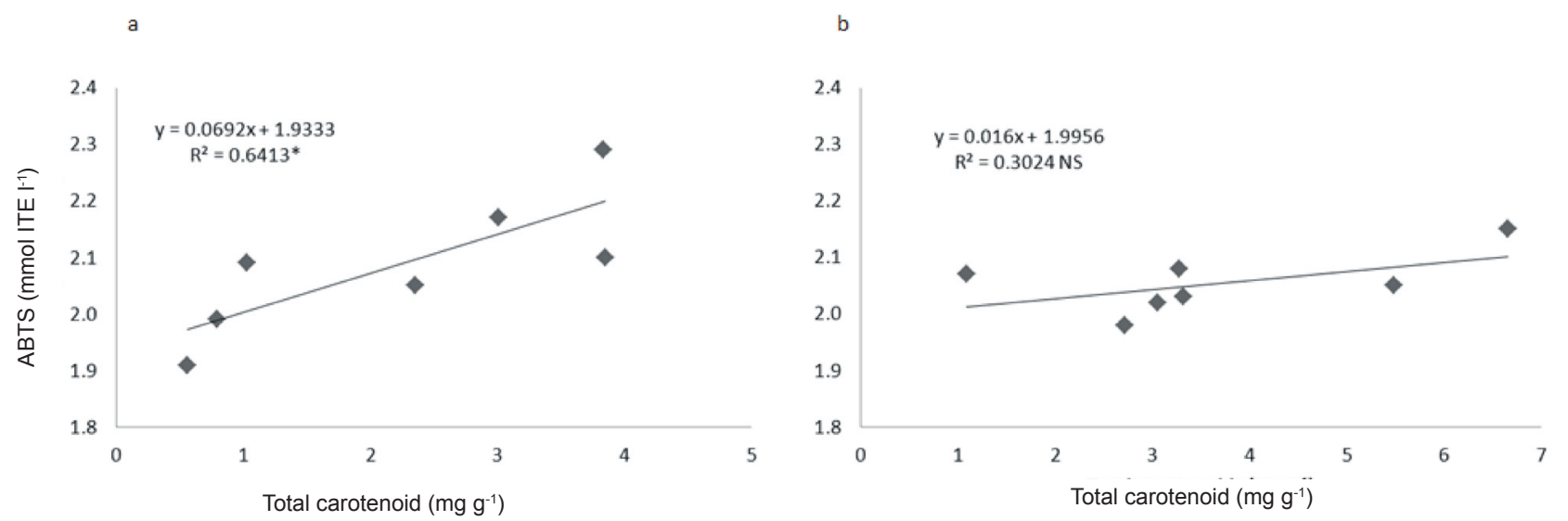

Fig. 3. Linear regression between the total carotenoid content $\left(\mathrm{mg} \mathrm{g}^{-1}\right)$ and antioxidant activity (mmol TE $\left.\mathrm{l}^{-1}\right)$ in the aqueous extracts of: $\mathrm{a}$ - lemon balm and b - peppermint leaf samples. Explanations as in Fig. 2.

compounds with a proven significant antioxidant effect, due to which they show a positive effect on human health (Roselló-Soto et al., 2015b). The total carotenoid content of the lemon balm aqueous extracts significantly correlate $(0.01<\mathrm{p}<0.05)$ with the antioxidant activity (ABTS) at a coefficient of determination $\mathrm{R}^{2}=0.6413$ (Fig. 3a). Linear regression analysis between the total carotenoid content and antioxidant activity of the aqueous peppermint samples did not show a significant correlation with the determined coefficient $\mathrm{R}^{2}=0.3024$ (Fig. 3b) and correlation coefficient $\mathrm{r}=0.549$ (Table 3). Carotenoids and their derivatives are compounds that exhibit strong antioxidant activity (Mueller and Boehm, 2011; Roselló-Soto et al., 2015b). In this research, the extraction method is the main reason why no significant correlation between the total chlorophyll, carotenoid content, and antioxidant activity was determined.

\section{CONCLUSIONS}

1. The extraction technique significantly affected the content of all the investigated bioactive compounds of the lemon balm and peppermint aqueous extracts.

2. With the conventional extraction method, higher contents of total phenolic compounds and antioxidant activity were determined, in comparison with ultrasonic extraction.

3. Ultrasonic extraction for 25 min yielded a significant total phenol content and antioxidant activity.

4. By ultrasonic extraction for $20 \mathrm{~min}$, higher values of total chlorophylls (chlorophyll a and b) and carotenoids were obtained, in comparison with the conventional method.

5. Application of ultrasound significantly shortens the extraction period compared with the conventional method in which the extract time amounts to $24 \mathrm{~h}$.

6. During ultrasonic extraction for 20 and $25 \mathrm{~min}$, high values of total phenolic compounds, total chlorophylls, carotenoids, and antioxidant activity were obtained.
7. A significant, positive correlation between the total phenol content and antioxidant activity of the aqueous lemon balm and peppermint extracts was determined.

\section{REFERENCES}

Abou-Arab A.E. and Abu-Salem M.F., 2010. Evaluation of bioactive compounds of Stevia rebaudiana leaves and callus. Afr. J. Food Sci., 4, 627-634.

Auclair S., Silberberg M., Gueux E., Morand C., Mazur A., Milenkovic D., and Scalbert A., 2008. Apple polyphenols and fibers attenuate atherosclerosis in apolipoprotein E-deficient mice. J. Agric. Food Chem., 56, 5558-5563.

Barba F.J., Esteve M.J., and Frígola A., 2010. Ascorbic acid is the only bioactive that is better preserved by high hydrostatic pressure than by thermal treatment of a vegetable beverage. J. Agric. Food Chem., 58, 10070-10075.

Barba F.J., Esteve M.J., Tedeschi P., Brandolini V., and Frígola A., 2013. A comparative study of the analysis of antioxidant activities of liquid foods employing spectrophotometric, fluorometric, and chemiluminescent methods. Food Anal. Methods, 6, 317-327.

Barba F.J., Esteve M.J., and Frígola A., 2014. Bioactive components from leaf vegetable products. Stud. Nat. Prod. Chem., 41, 321-346.

Barba F.J., Grimi N., and Vorobiev E., 2015a. Evaluating the potential of cell disruption technologies for green selective extraction of antioxidant compounds from Stevia rebaudiana Bertoni leaves. J. Food Eng., 149, 222-228.

Barba F.J., Grimi N., and Vorobiev E., 2015b. New approaches for the use of non-conventional cell disruption technologies to extract potential food additives and nutraceuticals from microalgae. Food Eng. Rev., 7, 45-62.

Bouchra C., Achouri M., Idrissi H.L.M., and Hmamouchi M., 2003. Chemical composition and antifungal activity of essential oils of seven Moroccan Labiatae against Botrytis cinerea Pers. J. Ethnopharmacol., 89, 165-169.

Caniova A. and Brandsteterova E., 2001. HPLC analysis of phenolic acids in Melissa officinalis. J. Liq. Chrom. Rel. Technol., 24, 2647-2659. 
Carbonell-Capella J.M., Barba F.J., Esteve M.J., and Frígola A., 2014. Quality parameters, bioactive compounds and their correlation with antioxidant capacity of commercial fruitbased baby foods. Food Sci. Technol. Int., 20, 479-487.

Criado N., Barba F.J., Frígola A., and Rodrigo D., 2014. Effect of Stevia rebaudiana on oxidative enzyme activity and its correlation with antioxidant capacity and bioactive compounds. Food Bioprocess Technol., 7, 1518-1525.

Cvjetko Bubalo M., Sabotin I., Radoš I., Valentinčič J., Bosiljkov T., Brnčić M., and Žnidaršič-Plazl P., 2013. A comparative study of ultrasound, microwave and microreactor-assisted imidazolium-based ionic liquid synthesis. Green Proc. Synth., 2, 579-590.

Dastmalchi K., Damien Dorman H.J., Oinonen P.P., Darwis Y., Laakso I., and Hiltunen R., 2008. Chemical composition and in vitro antioxidative activity of a lemon balm (Melissa officinalis L.) extract. Food Sci. Technol. -LWT, 41, 391-400.

De Vincenzi M., Maialetti F., Di Pascquale M., and Dessi M.R., 1991. Monographs on botanical flavouring substances used in foods. Fitoterapia, 62, 47-63.

Deng Q., Zinoviadou K.G., Galanakis C.M., Orlien V., Grimi N., Vorobiev E., Lebovka N., and Barba F.J., 2015. The effects of conventional and non-conventional processing on glucosinolates and its derived forms, isothiocyanates: extraction, degradation, and applications. Food Eng. Rev., 7, 357-381.

Foster S. and Tyler V.E., 1993. Tyler's Honest Herbal: A Sensible Guide to the Use of Herbs and Related Remedies. The Haworth Herbal Press, Binghamton, NY, USA.

Grimi N., Dubois A., Marchal L., Jubeau S., Lebovka N.I., and Vorobiev E., 2014. Selective extraction from microalgae Nannochloropsis sp. using different methods of cell disruption. Bioresource Technol., 153, 254-259.

Grzeszczuk M. and Jadczak D., 2009. Estimation of biological value of some species of mint (Mentha L.). Herba Polonica, 55, 193-199.

Guédon D.J. and Pasquier B.P., 1994. Analysis and distribution of flavonoid gycosides and rosmarinic acid in 40 Mentha $\mathrm{x}$ piperita clones. J. Agric. Food Chem. 42, 679-684.

Hajlaoui H., Snoussi M., BenJannet H., Mighri Z., and Bakhrouf A., 2008. Comparison of chemical composition and antimicrobial activities of Mentha longifolia L. sp. longifolia essential oil from two Tunisian localities (Gabes and Sidi Bouzid). Ann. Microbiol., 58, 103-110.

Herceg Z., Brnčić M., Jambrak Režek A., Rimac Brnčić S., Badanjak M., and Sokolić I., 2009. Possibility of application high intensity ultrasound in milk industry. Mljekarstvo, 59, 65-69.

Holm G., 1954. Chlorophyll mutations in barley. Acta Agr. Scand., 4, 457-471.

Hsu C.Y., Chao P.Y., Hu S.P., and Yang C.M., 2013. The Antioxidant and free radical scavenging activities of chlorophylls and pheophytins. Food Nutr. Sci., 4, 1-8.

İnce A.E., Şahin S., and Şümnü S.G., 2013. Extraction of phenolic compounds from melissa using microwave and ultrasound. Turk. J. Agric. For., 37, 69-75.

Kapp K., Hakala A.E., Anne Orav A., Pohjala L., Vuorela P., Püssa T., Vuorela H., and Raal A., 2013. Commercial peppermint (Mentha piperita L.) teas: Antichlamydial effect and polyphenolic composition. Food Res. Int., 53, 758-766.
Karasová G. and Lehotay J., 2006. Comparison of several extraction methods for the isolation of benzoic acid derivatives from Melissa officinalis. J. Liq. Chromatogr. Rel. Technol., 29, 1633-1644.

Komes D., Belščak-Cvitanović A., Horžić D., Marković K., and Kovačević Ganić K., 2011. Characterisation of pigments and antioxidant properties of three medicinal plants dried under different drying conditions. Proc. 11th Int. Congress Engineering and Food, May 22-26, Athens, Greece.

Kong W., Liu N., Zhang J., Yang Q., Hua S., Song H., and Xia C., 2014. Optimization of ultrasound-assisted extraction parameters of chlorophyll from Chlorella vulgaris residue after lipid separation using response surface methodology. J. Food Sci. Technol., 51, 2006-2013.

Koubaa M., Roselló-Soto E., Šic Žlabur J., Režek Jambrak A., Brnčić M., Grimi N., Boussetta N., and Barba F.J., 2015. Current and new insights in the sustainable and green recovery of nutritionally valuable compounds from Stevia rebaudiana Bertoni. J. Agric. Food Chem., 63, 6835-6846.

Kumcuoglu S., Yilmaz T., and Tavman S., 2014. Ultrasound assisted extraction of lycopene from tomato processing wastes. J. Food Sci. Technol., 51, 4102-4107.

Loranty A., Rembialkowska E., Rosa E.A.S., and Bennett R.N., 2010. Identification, quantification and availability of carotenoids and chlorophylls in fruit, herb and medicinal teas. J. Food Compos. Anal. 23, 432-441.

Lv J., Huang H., Yua L., Whent M., Niu Y., Shi H., Wang T.T.Y., Luthria D., Charles D., and Yu L.L., 2012. Phenolic composition and nutraceutical properties of organic and conventional cinnamon and peppermint. Food Chem., 132, 1442-1450.

Miller N.J., Diplock A.T., Rice-Evans C., Davies M.J., Gopinathan V., and Milner A., 1993. A novel method for measuring antioxidant capacity and its application to monitoring the antioxidant status in premature neonates. Clin. Sci., 84, 407-412.

Mueller L. and Boehm V., 2011. Antioxidant activity of $\beta$-carotene compounds in different in vitro assays. Molecules, 16, 1055-1069.

Naik G.H., Priyadarsini K.I., and Mohan H., 2006. Free radical scavenging reactions and photochemical analysis of triphala, an ayurvedic formulation. Curr. Sci., 90, 1100-1105.

Najafian S. and Rowshan V., 2013. Polyphenolic compounds of Mentha longifolia and Lemon Balm (Melissa officinalis L.) in Iran. Int. Res. J. Appl. Basic Sci., 4, 608-612.

Oh J., Jo H., Cho A.R., Kim S.J., and Han J., 2013. Antioxidant and antimicrobial activities of various leafy herbal teas. Food Control, 31, 403-409.

Ough C.S. and Amerine M.A., 1998. Methods for Analysis of Musts and Wines. Wiley Press, Washington, DC, USA.

Riachi L.G. and De Maria C.A.B., 2015. Peppermint antioxidants revisited. Food Chem., 176, 72-81.

Roselló-Soto E., Galanakis C.M., Brnčić M., Orlien V., Trujillo F.J., Mawson R., Knoerzer K., Tiwari B.K., and Barba F.J., 2015a. Clean recovery of antioxidant compounds from plant foods, by products and algae assisted by ultrasounds processing: Modeling approaches to optimize processing conditions. Trends Food Sci. Tech., 42, 134-149. 
Roselló-Soto E., Koubaa M., Moubarik A., Lopes R.P., Saraiva J.A., Boussetta N., Grimi N., and Barba F.J., 2015b. Emerging opportunities for the effective valorization of wastes and by-products generated during olive oil production process: Non-conventional methods for the recovery of high-added value compounds. Trends Food Sci. Tech., 2, 296-310

Ross K.A., Beta T., and Arntfield S.D., 2009. A comparative study on the phenolic acids identified and quantified in dry beans using HPLC as affected by different extraction and hydrolysis methods. Food Chem., 113, 336-344.

Saljoqi A.U.R., Afridi M.K., Khan S.A., and Rehman S., 2006. Effects of six plant extracts on rice weevil Sitophilus oryzae L. in the stored wheat grains. J. Agric. Biol. Sci., 1, 1-5.

SAS/STAT, 2010. Ver. 9.3., SAS Institute, Cary, NC.

Shukla S., Mehta A., Mehta P., and Bajpai V.K., 2012. Antioxidant ability and total phenolic content of aqueous leaf extract of Stevia rebaudiana Bert. Exp. Toxicol. Pathol., 64, 807-811.
Sinkovič L., Demšar L., Žnidarčič D., Vidrih R., Hribar J., and Treutter D., 2015. Phenolic profiles in leaves of chicory cultivars (Cichorium intybus L.) as influenced by organic and mineral fertilizers. Food Chem., 166, 507-513.

Šic Žlabur J., Voća S., Dobričević N., Rimac Brnčić S., Dujmić F., and Brnčić M., 2015. Optimization of ultrasound assisted extraction of functional ingredients from Stevia rebaudiana Bertoni leaves. Int. Agrophys., 29, 231-237.

Wettstein D., 1957. Chlorophyll letale und der submikroskopische Formwechsel der Plastiden. Exp. Cell. Res., 12, 427-434

Yamasaki K., Nakano M., Kawahata T., Mori H., Otake T., Ueba N., Oishi I., Inami R., Yamane M., Nakamura M., Murata H., and Nakanishi T., 1998. Anti-HIV-1 activity of herbs in Labiatae. Biol. Pharm. Bull., 21, 829-833.

Zinoviadou K.G., Galanakis C.M, Brnčić M., Grimi N., Boussetta N., Mota M.J., Saraiva J., Patras A., Tiwari B.K., and Barba F.J., 2015. Fruit juice sonication: Implications on food safety, physicochemical and nutritional properties. Food Res. Int. DOI 0.1016/j.foodres.2015.05.032. 